\title{
IN VITRO EFFECTS OF POLYPHENOLS EXTRACTED FROM THE AROEIRA PLANT (SCHINUS TEREBINTHIFOLIUS RADDI) ON THE GROWTH OF PROSTATE CANCER CELLS (LNCaP, PC-3 AND DU145)
}

\author{
Luis Carlos Queires Universidade do Estado da Bahia, \\ Departamento de Ciências Exatas e \\ da Terra, DECET, Alagoinhas, Bahia, \\ Brazil. \\ Michel Crépin Université Paris XIII, SBM, Bobigny, \\ France. \\ Francis Vacherot Université Paris XII, Service \\ d'Urologie, CHU Henri Mondor, \\ Créteil, France. \\ Alex de la Taille Université Paris XII, Service \\ d'Urologie, CHU Henri Mondor, \\ Créteil, France. \\ Luiz Erlon Rodrigues Laboratório de Pesquisas Básicas - \\ Escola Bahiana de Medicina e Saúde \\ Pública, Salvador, Bahia, Brazil.
}

\begin{abstract}
Despite the existence of various types of antineoplastic treatments of prostate cancer, most of them induce apoptosis in the tumor cells by means of synthetic or natural drugs. The aim of this work was to study the antiproliferative action of methanolic and aqueous extracts from the leaves of the aroeira plant ( $\underline{\text { Schinus }}$ terebinthifolius) a plant from the Northeast from Brazil over isolated prostate cancer cell cultures. The extracts were tested in isolated cell lineages from non hormone-dependent cancers (DU145 e PC-3), as well as in hormone-dependent ones (LNCaP). The cells were cultivated in a RPMI medium and were incubated at $37^{\circ} \mathrm{C}$ in a $5 \% \mathrm{CO}_{2}$, humid environment. The activities of the extracts were evaluated within 3 and 6 days of cellular growth. The aqueous extract was more effective than the methanolic one in the inhibition of cell multiplication in all the lineages tested.
\end{abstract}

Keywords: Polyphenols; Aroeira; Prostate cancer.

\section{INTRODUCTION}

The development and functionality of the prostate gland depends fundamentally on testosterone, which penetrates by diffusion into the prostatic cells where it is then converted into other steroids, principally dihydrotestosterone (DHT). These steroids act in the development of the gland, being implicated in the production of growth factors such as insulin-like growth factor (IGF) through the stroma cells. ${ }^{(1)}$

In 1941, Huggins and Hodges cited by Fluchter et al. ${ }^{(2)}$ demonstrated that in dogs with prostate cancer, surgical castration led to atrophy of the gland, thereby confirming the important effect of androgen for the development not only of the prostate but also of its neoplasia. Similar results were obtained by Niu et al., ${ }^{(3)}$ confirming that castration in dogs 
Queiroz et al. In vitro effects of polyphenols extracted from the aroeira plant (Schinus terebinthifolius Raddi) on the growth of prostate cancer cells (LNCaP, PC-3 and DU145)

leads to atrophy of the prostate and cell death. The latter study found that in these animals, proliferation, differentiation and even regression in the development of the stroma and epithelial cells of the prostate were androgen-dependent.

Apoptosis may be triggered by the activation and deactivation of certain genes. Some such as MYC, FOS and JUN are proto-oncogenic, while others such as B cell lymphoma-2 (Bcl-2) and tumor suppressor gene TP53 act by regulating apoptosis.

The importance of hormones in the development of prostate cancer may be explained by the effects resulting from their relationship with androgen receptors (AR). In brief, the biological effects caused by these hormones include their own gene expression, their modulation through transcription, post-transcription and post-translation, and their interaction with coactivators and corepressors. ${ }^{(4)}$

A major step in the treatment of cancers in general consists of inducing the process of apoptosis in the cancer cells. Nevertheless, hormone treatment implemented in patients with prostate tumors does not guarantee that all the cancer cells undergo apoptosis. Those that survive become more resistant to treatment, originating a new cell line that will multiply continuously irrespective of the absence of androgen. The majority of in vitro studies with neoplastic prostate cells use lines that are refractory to hormone treatment such as PC-3 and DU145, as well as the non-resistant line, LNCaP.

Cell survival and multiplication are associated with metabolic mechanisms involving the proteasome, a structure with catalytic activities consisting of the inhibition of apoptosis and the promotion of cell multiplication. ${ }^{(5,6)}$

In an attempt to trigger apoptosis in neoplastic cells, compounds consisting of synthetic or natural drugs that induce this process are used. Plant compounds with apoptotic effects are currently undergoing tests as possible substitutes for synthetic drugs. In 2001, $\mathrm{Chenn}^{(7)}$ submitted rats with prostate cancer to treatment with a dietary supplement composed of a mixture of eight, supposedly medicinal, herbs and confirmed that their active ingredients were cytotoxic and cytostatic, also demonstrating that these effects did not depend entirely on the presence of androgen receptors.

Kazi et al. ${ }^{(8)}$ reported that musaceae extracts, which contain a large concentration of tannic acid, induced apoptosis in hormone-dependent prostate cancer cells (LNCaP), and also inhibited proteasome activity in cells infected with simian vacuolating virus (SV40). Nevertheless, this same effect was not achieved in healthy fibroblasts (WI-38 line) isolated from humans. 
Queiroz et al. In vitro effects of polyphenols extracted from the aroeira plant (Schinus terebinthifolius Raddi) on the growth of prostate cancer cells (LNCaP, PC-3 and DU145)

In search of new treatments, the extracts or active ingredients of various plant origins, separated using alcohol or aqueous solvents, have been tested. In 2007, Gonzales et al. ${ }^{(9)}$ showed that extracts of Lepidium meyenii successfully reduced prostate size in rats with chemically induced prostatic hyperplasia.

Therefore, the objective of this study was to evaluate in vitro the antiproliferative effects of the methanol and aqueous extracts of the leaves of the Brazilian aroeira plant (Schinus terebinthifolius, Raddi) in non-hormone-dependent prostate cancer cell lines, DU145 and $\mathrm{PC}-3$, as well as in the hormone dependent line, $\mathrm{LNCaP}$.

\section{METHODS}

The technique used in processing the aroeira leaves and obtaining the aqueous (AE) and methanol extracts (ME)

Approximately 250 grams of aroeira leaves were collected and washed in running water. After drying in an oven at $60^{\circ} \mathrm{C}$ until reaching constant weight, they were triturated and the polyphenols were extracted using a slightly modified version of the technique described by Wagner and Bladt. ${ }^{(10)}$ For each gram of triturated leaves, $10 \mathrm{~mL}$ of methanol were used in an initial hot extraction. Following filtration, the final volume was reduced to one-quarter in a rotatory evaporator heated to $60^{\circ} \mathrm{C}$. Next, it was filtered under vacuum, using a Büchner funnel and sterilized membranes with a porosity of $5 \mu \mathrm{m}$, and stored in a dark-colored bottle for a maximum period of three months in a vacuum desiccator under refrigeration at a temperature of around $4^{\circ} \mathrm{C}$.

\section{Aqueous extract}

For each gram of dry, triturated aroeira leaves placed in a $200 \mathrm{~mL}$ beaker, $10 \mathrm{~mL}$ of boiled, distilled water were added and maintained under constant agitation for 15 minutes. Next, the suspension was filtered in qualitative filter paper and centrifuged at $8000 \mathrm{~g}$ for 10 minutes. The supernatant was transferred to a $400 \mathrm{~mL}$ decanting apparatus, mixed with $20 \mathrm{~mL}$ of chloroform and agitated for 5 minutes. After separation of the phases, the chloroform fraction was discarded and the aqueous fraction reduced to one-fifth of its volume in a rotatory evaporator heated to $70^{\circ} \mathrm{C}$ under negative pressure. The resulting aqueous extract (AE) was filtered under vacuum using membranes with a porosity of $5 \mu \mathrm{m}$, and stored in a 
Queiroz et al. In vitro effects of polyphenols extracted from the aroeira plant (Schinus terebinthifolius Raddi) on the growth of prostate cancer cells (LNCaP, PC-3 and DU145)

dark-colored bottle in a vacuum desiccator under refrigeration at a temperature of around $4{ }^{\circ} \mathrm{C}$ for a maximum period of three months.

\section{Calculation of the residual dry weight of the extracts}

Known volumes of the methanol and aqueous extracts were evaporated separately until completely dry in previously weighed recipients. The weight of the dry residue permitted the concentration in $\mathrm{mg} / \mathrm{mL}$ of the original solutions to be calculated.

\section{Treatment of the in vitro samples}

Three prostate cancer cell lines were used: DU145, LNCaP and PC-3, cultivated in RPMI 1640 culture medium containing phenol as an indicator and 10\% (v/v) fetal calf serum (FCS), $1 \%$ penicillin and streptomycin and stabilized glutamine. The cell lines were distributed in separate, flat-bottomed, 96-well plates in an initial proportion of 7500 cells/100 $\mu \mathrm{L}$ of culture medium per well and maintained in a culture chamber at $37^{\circ} \mathrm{C}$ with $5 \% \mathrm{CO}_{2}$. With the exception of the control group, the methanol and aqueous extracts were added separately to the culture medium contained in each well in quantities of $15,75,150,225,375$, 525 and $750 \mu \mathrm{g}$ per well. The results were analyzed after three and six days of treatment.

\section{Colorimetric test to measure cell growth}

On the third and sixth days, the supernatant from each well was aspirated and substituted by $100 \mu \mathrm{L}$ of a solution of MTT [3-(4,5-dimethylthiazol-2-yl)-2,5diphenyltetrazolium bromide]. This solution was prepared by dissolving $1 \mathrm{mg}$ of MTT in each $1 \mathrm{~mL}$ of culture medium (RPMI) without phenol. Next, the cells were incubated at $37^{\circ} \mathrm{C}$ for one hour. After this time, the supernatant containing the MTT solution was aspirated and 100 $\mu \mathrm{L}$ of isopropanol were added. After 10 minutes at $37^{\circ} \mathrm{C}$, optical density was measured in a Dynatech $^{\circledR}$ reader at $550 \mathrm{~nm}$.

\section{Measurement of total polyphenols}

Total polyphenol content of the plant extracts was detected quantitatively using Folin reagent in accordance with the technique used by Heimler et al. ${ }^{(11)}$ For each $100 \mu \mathrm{L}$ of the 
Queiroz et al. In vitro effects of polyphenols extracted from the aroeira plant (Schinus terebinthifolius Raddi) on the growth of prostate cancer cells (LNCaP, PC-3 and DU145)

extract, $500 \mu \mathrm{L}$ of an alkaline copper solution containing $162 \mathrm{mM} \mathrm{Na}_{2} \mathrm{CO}_{3}, 2.14 \mathrm{mM}$ potassium sodium tartrate $\left(\mathrm{KNaC}_{4} \mathrm{H}_{4} \mathrm{O}_{6}\right), 90 \mathrm{mM} \mathrm{NaOH}$ and $0.4 \mathrm{mM} \mathrm{CuSO}_{4}$ were added. After 5 minutes, $100 \mu \mathrm{L}$ of Folin reagent were added, diluted with distilled water in a proportion of 1:3, shaken and left to rest for 30 minutes to develop a bluish color. Optical density was measured at $750 \mathrm{~nm}$ against a blank test containing all the reagents with the exception of the polyphenol extract, which was substituted by an equal volume of distilled water.

\section{Statistical analysis}

The data were evaluated using analysis of variance (ANOVA) and Student's t-test. Significance was defined as $\mathrm{p}<0.05$. Results are expressed as means \pm standard deviations and based on three repeat experiments.

\section{RESULTS}

The use of methanol and water as extracting solvents for the aroeira leaves resulted in extracts with different densities and quantities of residues. The ME retained 1.53 times more residue than the aqueous extract. Nevertheless, both solvents successfully isolated important phenolic compounds. Table 1 provides a qualitative summary of the presence of phenols and the dry weights of the alcohol and aqueous extracts. Methanol extraction produced a solution with more residual dry weight than that produced when water was used, perhaps due to the ability of methanol to emulsify some lipids, whereas in the aqueous extract the removal of the polar lipids was achieved with the use of chloroform.

Table 1 - Dry weight of the aqueous and methanol extracts of the aroeira leaf

\begin{tabular}{l|c|c}
\hline \multirow{2}{*}{\multicolumn{1}{c}{ Type of extraction }} & \multicolumn{2}{c}{ Dry weight in $\mathbf{~ m g / m L}$} \\
\cline { 2 - 3 } & AE $(\mathbf{m g} / \mathbf{m L})$ & ME $(\mathbf{m g} / \mathbf{m L})$ \\
\hline Methanol extraction & - & 23 \\
\hline Aqueous extraction & 15 & - \\
\hline Presence of phenols (biuret-Folin reaction) & + & + \\
\hline
\end{tabular}

Application of the concentrated methanol (ME) and aqueous extracts (AE) reduced cell viability in the three prostate cell lines tested. Their effects were dependent on the concentrations of the extracts used in the cultures (Figure 1). The substitution of ME for pure 
Queiroz et al. In vitro effects of polyphenols extracted from the aroeira plant (Schinus terebinthifolius Raddi) on the growth of prostate cancer cells (LNCaP, PC-3 and DU145)

methanol showed that the antiproliferative effects listed in Table 2 were due to the compounds present in the ME and not to the toxicity of the alcohol itself.

Table 2 - Effects of the different extracts on the viability of prostate cancer cells cultivated for 3 days (shown as number of times).

\begin{tabular}{|c|c|c|c|c|c|c|c|c|c|}
\hline \multirow[b]{2}{*}{ Cell line } & \multirow[b]{2}{*}{ Extract } & \multicolumn{8}{|c|}{ Micrograms of solid residue of the extract per $100 \mu \mathrm{L}$ of culture } \\
\hline & & $\mathbf{0}$ & 15 & 75 & 150 & 225 & 375 & 525 & $\begin{array}{c}750 \\
\left(\% I^{*}\right)\end{array}$ \\
\hline \multirow{3}{*}{ LNCaP } & Aqueous & 1 & 0,98 & 0,96 & 0,60 & 0,29 & 0,17 & 0,16 & $\begin{array}{c}0,14 \\
(85,9)\end{array}$ \\
\hline & Methanol & 1 & 0,94 & 0,77 & 0,79 & 0,57 & 0,35 & 0,17 & $\begin{array}{c}0,18 \\
(82,3)\end{array}$ \\
\hline & $\begin{array}{l}\text { Counter-test } \\
\text { with pure } \\
\text { methanol }\end{array}$ & 1 & 0,83 & 0,70 & 0,79 & 0,60 & 0,62 & 0,53 & $\begin{array}{c}0,47 \\
(52,7)\end{array}$ \\
\hline \multirow{3}{*}{ PC-3 } & Aqueous & 1 & 0,97 & 0,93 & 0,90 & 0,73 & 0,35 & 0,19 & $\begin{array}{c}0,15 \\
(85,5)\end{array}$ \\
\hline & Methanol & 1 & 1,04 & 1,05 & 1,03 & 0,98 & 0,95 & 0,82 & $\begin{array}{c}0,64 \\
(35,6)\end{array}$ \\
\hline & $\begin{array}{c}\text { Counter-test } \\
\text { with pure } \\
\text { methanol }\end{array}$ & 1 & 0,97 & 0,98 & 0,98 & 0,95 & 0,93 & 0,94 & $\begin{array}{l}0,90 \\
(9,9)\end{array}$ \\
\hline \multirow{3}{*}{ DU145 } & Aqueous & 1 & 1,02 & 0,68 & 0,21 & 0,15 & 0,15 & 0,19 & $\begin{array}{c}0,15 \\
(84,6)\end{array}$ \\
\hline & Methanol & 1 & 0,78 & 0,74 & 0,70 & 0,59 & 0,68 & 0,39 & $\begin{array}{l}0,23 \\
(77)\end{array}$ \\
\hline & $\begin{array}{l}\text { Counter-test } \\
\text { with pure } \\
\text { methanol ** }\end{array}$ & 1 & 0,81 & 0,76 & 0,83 & 0,84 & 0,84 & 0,73 & $\begin{array}{c}0,83 \\
(16,9)\end{array}$ \\
\hline
\end{tabular}

$* \% \mathrm{I}=$ The values in parentheses are the percentages of inhibition of the extracts.

$* *=$ Tests in which the cells were treated exclusively with methanol. 
Figure 1 - Effects on cell growth three days after application of the extracts. In A, the aqueous extract (AE) was used, and in B, the methanol extract (ME) was used. Each curve was constructed using mean values

\section{A}

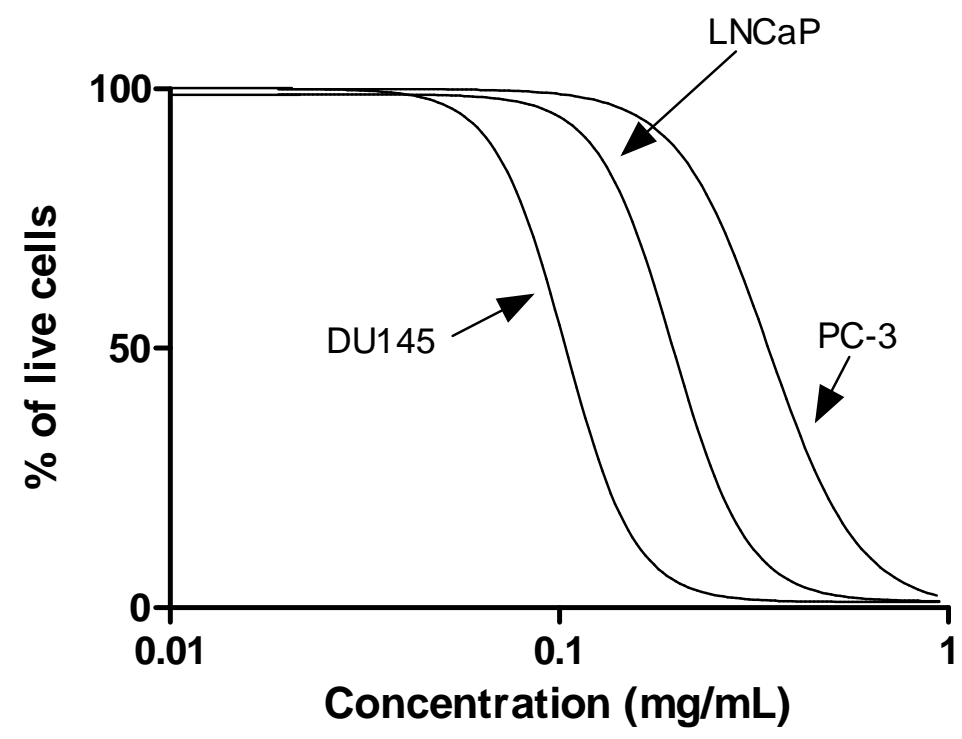

B

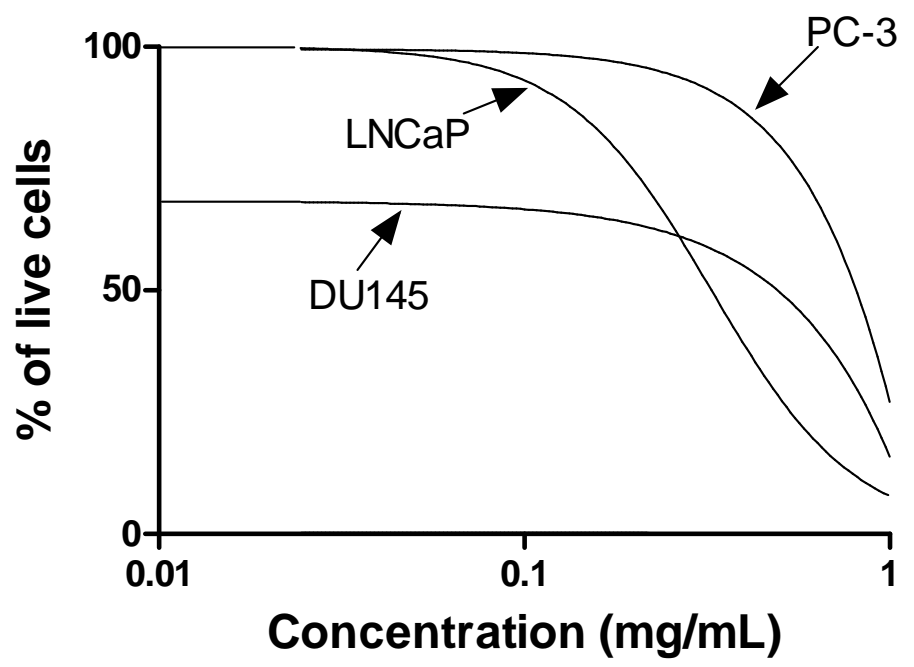

Figure 2 shows that the inhibitory effects of the extract were practically the same in the cells treated for 3 and 6 days, a fact that is confirmed by the similar $\mathrm{IC}_{50}$ values (index representing half the viable cells in each culture). Within the same cell line, the $\mathrm{IC}_{50}$ 
Queiroz et al. In vitro effects of polyphenols extracted from the aroeira plant (Schinus terebinthifolius Raddi) on the growth of prostate cancer cells (LNCaP, PC-3 and DU145)

corresponding to the aqueous extract was always the result of a lower polyphenol concentration. The DU145 line was the one most affected by this extract, its $\mathrm{IC}_{50}$ value being the lowest of all. Furthermore, it was the line with the highest correlation $\left(\mathrm{R}^{2}=0.9922\right)$ between cell viability and the concentration of the extracts used. Of the three lines tested, PC3 was the least affected by the aqueous extract (Figure 2).

Figure $2-\mathrm{IC}_{50}$ of the extracts according to incubation time

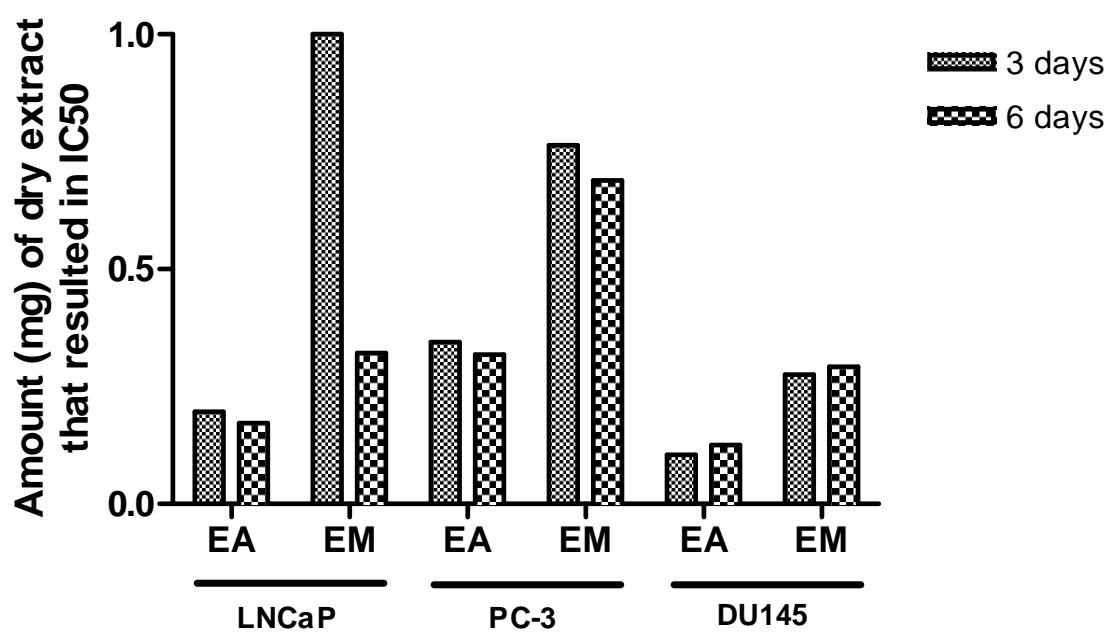

The different types of extracts obtained from the leaves of the aroeira affected the survival of the three prostate cell lines tested in different ways.

The effects of the two extracts presented in Table 2 show that the viability of the DU145 line was the most affected. Treatment with the aqueous extract at the concentration of $150 \mu \mathrm{g}$ was able to reduce the number of living cells to one-fifth (20\%). The ME reduced the number of living cells of the LNCaP line to one-sixth (17\%) when a very much higher concentration $(525 \mu \mathrm{g})$ was used.

\section{DISCUSSION}

In 2003, Kazi et al. ${ }^{(8)}$ showed that tannic acid, a polyphenol, inhibited proteasome activity and induced apoptosis in isolated human prostate tumor cells. These effects, in addition to those presented by different natural compounds such as some triterpenes, steroids and various polyphenols, are possibly a result of their binding to the proteasome subunit $\beta 5$, a 
Queiroz et al. In vitro effects of polyphenols extracted from the aroeira plant (Schinus terebinthifolius Raddi) on the growth of prostate cancer cells (LNCaP, PC-3 and DU145)

monomer present in the heptameric beta rings $(\beta 7, \beta 7)$ that form part of this catalytic protein complex. ${ }^{(12-16)}$

It is probable that the molecules that affect proteasome activity may also aid in the control or treatment of neoplasias. According to Garg et al., ${ }^{(17)}$ this association was demonstrated by the anticarcinogenic effect of some polyphenols extracted from plants used in medicinal teas. Landis-Piwowar et al. ${ }^{(18)}$ showed that these substances may render cells sensitive to therapeutic agents by acting as proteasome inhibitors.

Naujokat et al. ${ }^{(19)}$ showed that proteolytic activities are clearly associated with cell survival and multiplication. The increase in the $M Y C$ protooncogene expression that codifies a nuclear phosphoprotein whose expression is enhanced or deregulated in tumors reduced the rate of cell multiplication in fibroblasts isolated from rats. ${ }^{(20,21)}$ The quantitative reduction of this phosphoprotein is the result of a proteasome-mediated proteolytic process. Studies carried out by Chu et al. ${ }^{(22)}$ and Naujokat et al. ${ }^{(23)}$ also showed that cell proliferation is associated with proteasome-mediated protein degradation.

According to Nam et al. ${ }^{(24)}$ and Smith et al., ${ }^{(25)}$ polyphenols with antineoplastic activities are associated with the proteolytic process. They bind specifically to the proteasome beta-type subunits via ester bonds. Studies carried out by Aggarwal et al. ${ }^{(26)}$ and Lin $^{(27)}$ using curcumin, a polyphenol found in Curcuma longa, a plant that is native to southern Asia, showed inhibitory effects of the proteasome-mediated intracellular proteolytic processes. Epigallocatechin and epigallocatechin gallate are polyphenols that are found in a wide variety of plants, principally green tea (Camellia sinensis), and have been shown to act in various stages of carcinogenesis. They appear to inhibit protein kinases such as mitogen-activated protein kinases (MAPK), proteasomes, and the processes of angiogenesis and metastasis. Moreover, they are capable of regulating the metalloproteinase expression of the extracellular matrix while, on the other hand, inducing apoptotic processes in tumor cells. ${ }^{(28-30)}$

The results obtained in this study show that DU145, of the three lines tested, was the one most affected by the aqueous extract. Curiously, this is a non-hormone-dependent line, a fact that greatly hampers the treatment of individuals affected by this type of prostate cancer. These experimental results appear to suggest that the substances present in the aqueous extract of the aroeira leaf may perhaps reduce the survival capacity of the tumor cells and render them more sensitive to conventional treatments. 
Queiroz et al. In vitro effects of polyphenols extracted from the aroeira plant (Schinus terebinthifolius Raddi) on the growth of prostate cancer cells (LNCaP, PC-3 and DU145)

\section{REFERENCES}

1. Le H, Arnold JT, Mcfann KK, Blackman MR. DHT and testosterone, but not DHEA or E2, differentially modulate IGF-I, IGFBP-2, and IGFBP-3 in human prostatic stromal cells. Am J Physiol Endocrinol Metab. 2006; 290(5): E952-960.

2. Fluchter SH, Weiser R, Gamper, C. The role of hormonal treatment in prostate cancer. Recent Results Cancer Res. 2007; 175: 211-237.

3. Niu YJ, Ma TX, Zhang J, Xu Y, Han RF, Sun G. Androgen and prostatic stroma. Asian J Androl. 2003; 5(1): 19-26.

4. Brum IS, Spritzer PM, Brentani MM. [Molecular biology in the prostate neoplasia]. Arq Bras Endocrinol Metabol. 2005; 49(5): 797-804.

5. Dou QP, Li B. Proteasome inhibitors as potential novel anticancer agents. Drug Resist Updat. 1999; 2(4): 215-223.

6. Kisselev AF, Goldberg AL. Proteasome inhibitors: from research tools to drug candidates. Chem Biol. 2001; 8(8): 739-758.

7. Chenn S. In vitro mechanism of PC SPES. Urology. 2001; 58(2 Suppl 1): 28-35; discussion 38 .

8. Kazi A, Urbizu DA, Kuhn DJ, Acebo AL, Jackson ER, Greenfelder GP et al. A natural musaceas plant extract inhibits proteasome activity and induces apoptosis selectively in human tumor and transformed, but not normal and non-transformed, cells. Int J Mol Med. $2003 ; 12(6): 879-887$.

9. Gonzales GF, Vasquez V, Rodriguez D, Maldonado C, Mormontoy J, Portella J et al. Effect of two different extracts of red maca in male rats with testosterone-induced prostatic hyperplasia. Asian J Androl. 2007; 9(2): 245-251.

10. Wagner A, Bladt S. Screening of unknown commercial drugs. In: Bladt S, Rickl, V. Plant Drug Analysis - A Thin Layer Chromatography Atlas. Berlin: Springer-Verlag; 1996. p. 349354.

11. Heimler D, Isolani L, Vignolini P, Tombelli S, Romani, A. Polyphenol content and antioxidative activity in some species of freshly consumed salads. J Agric Food Chem. 2007; 55(5): 1724-1729.

12. Marambaud P, Zhao H, Davies P. Resveratrol promotes clearance of Alzheimer's disease amyloid-beta peptides. J Biol Chem. 2005; 280(45): 37377-37382.

13. Daniel KG, Landis-Piwowar KR, Chen D, Wan SB, Chan TH, Dou QP. Methylation of green tea polyphenols affects their binding to and inhibitory poses of the proteasome beta5 subunit. Int J Mol Med. 2006; 18(4): 625-632. 
Queiroz et al. In vitro effects of polyphenols extracted from the aroeira plant (Schinus terebinthifolius Raddi) on the growth of prostate cancer cells (LNCaP, PC-3 and DU145)

14. Yang H, Shi G, Dou QP. The tumor proteasome is a primary target for the natural anticancer compound Withaferin A isolated from "Indian winter cherry". Mol Pharmacol. 2007; 71(2): 426-437.

15. Yang H, Landis-Piwowar KR, Chen D, Milacic V, Dou QP. Natural compounds with proteasome inhibitory activity for cancer prevention and treatment. Curr Prot Pept Sci. 2008; 9(3): 227-239.

16. Yang H, Landis-Piwowar KR, Lu D, Yuan P, Li L, Reddy, GP et al. Pristimerin induces apoptosis by targeting the proteasome in prostate cancer cells. J Cell Biochem. 2008; 103(1): 234-244.

17. Garg AK, Buchholz TA, Aggarwal, BB. Chemosensitization and radiosensitization of tumors by plant polyphenols. Antioxid Redox Signal. 2005; 7(11-12): 1630-1647.

18. Landis-Piwowar KR, Milacic V, Chen D, Yang H, Zhao Y, Chan TH et al. The proteasome as a potential target for novel anticancer drugs and chemosensitizers. Drug Resist Updat. 2006; 9(6): 263-273.

19. Naujokat C, Sezer O, Zinke H, Leclere A, Hauptmann S, Possinger K. Proteasome inhibitors induced caspase-dependent apoptosis and accumulation of p21WAF1/Cip1 in human immature leukemic cells. Eur J Haematol. 2000; 65(4): 221-236.

20. Goga A, Yang D, Tward AD, Morgan DO, Bishop JM. Inhibition of CDK1 as a potential therapy for tumors over-expressing MYC. Nat Med. 2007; 13(7): 820-827.

21. Wang H, Mannava S, Grachtchouk V, Zhuang D, Soengas MS, Gudkov AV et al. c-Myc depletion inhibits proliferation of human tumor cells at various stages of the cell cycle.

Oncogene. 2008; 27(13): 1905-1915.

22. Chu I, Arnaout A, Loiseau S, Sun J, Seth A, Mcmahon C et al. Src promotes estrogendependent estrogen receptor alpha proteolysis in human breast cancer. J Clin Invest. 2007; 117(8): 2205-2215.

23. Naujokat C, Fuchs D, Berges C. Adaptive modification and flexibility of the proteasome system in response to proteasome inhibition. Biochim Biophys Acta. 2007; 1773(9): 13891397.

24. Nam S, Smith DM, Dou QP. Ester bond-containing tea polyphenols potently inhibit proteasome activity in vitro and in vivo. J Biol Chem. 2001; 276(16): 13322-13330.

25. Smith DM, Daniel KG, Wang Z, Guida WC, Chan TH, Dou QP. Docking studies and model development of tea polyphenol proteasome inhibitors: applications to rational drug design. Proteins. 2004; 54(1): 58-70.

26. Aggarwal BB, Banerjee S, Bharadwaj U, Sung B, Shishodia S, Sethi G. Curcumin induces the degradation of cyclin $\mathrm{E}$ expression through ubiquitin-dependent pathway and up-regulates cyclin-dependent kinase inhibitors p21 and p27 in multiple human tumor cell lines. Biochem Pharmacol. 2007; 73(7): 1024-1032. 
Queiroz et al. In vitro effects of polyphenols extracted from the aroeira plant (Schinus terebinthifolius Raddi) on the growth of prostate cancer cells (LNCaP, PC-3 and DU145)

27. Lin JK. Molecular targets of curcumin. Adv Exp Med Biol. 2007; 595: 227-243.

28. Chen L, Zhang HY. Cancer preventive mechanisms of the green tea polyphenol (-)epigallocatechin-3-gallate. Molecules. 2007; 12(5): 946-957.

29. Landis-Piwowar KR, Huo C, Chen D, Milacic V, Shi G, Chan TH et al. A novel prodrug of the green tea polyphenol (-)-epigallocatechin-3-gallate as a potential anticancer agent. Cancer Res. 2007; 67(9): 4303-4310.

30. Shankar S, Ganapathy S, Srivastava, RK. Green tea polyphenols: biology and therapeutic implications in cancer. Front Biosci. 2007; 12: 4881-4899. 